Applied Geochemistry, 74, (2016) 109 - 121

\title{
Use of GEMAS data for risk assessment of cadmium in European agricultural and grazing land soil under the REACH Regulation
}

Manfred Birke a, *, Clemens Reimann b, Koen Oorts c, Uwe Rauch d, Alecos Demetriades e, Enrico Dinelli f, Anna Ladenberger g, Josip Halamic h, Mateja Gosar i, Fabian Jahne-Klingberg a, The GEMAS Project Team1

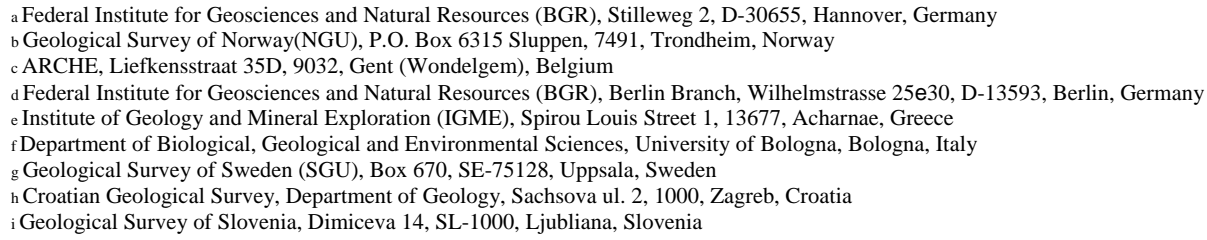

Over 4000 soil samples were collected for the "Geochemical Mapping of Agricultural and Grazing Land Soil of Europe" (GEMAS) project carried out by the EuroGeoSurveys Geochemistry Expert Group. Cadmium concentrations are reported for the $<2 \mathrm{~mm}$ fraction of soil samples from regularly ploughed fields (agricultural soil, Ap, $0-20 \mathrm{~cm}, \mathrm{~N}-2218$ ) and grazing land soil (Gr, $0-10 \mathrm{~cm}, \mathrm{~N}-2127)$. The samples were collected in 33 European countries, covering 5.6 million $\mathrm{km}^{2}$ at a sample density of 1 sample each per $2500 \mathrm{~km}^{2}$ and were analysed in an aqua regia extraction followed by an ICP-MS finish. The median Cd value is $0.181 \mathrm{mg} / \mathrm{kg}$ for the $\mathrm{Ap}$ and $0.202 \mathrm{mg} / \mathrm{kg}$ for the $\mathrm{Gr}$ soil samples. The data allow a directly comparable country-specific regional exposure and risk characterisation for all EU countries covered. Direct risks of $\mathrm{Cd}$ for terrestrial organisms are only predicted for a few isolated sample sites: $2.3 \%$ of the Ap and $4.5 \%$ of the Gr sites, respectively.

1 The GEMAS Project Team: S. Albanese, M. Andersson, R. Baritz, M.J. Batista, A. Bel-Ian, D. Cicchella, B. De Vivo,W. De Vos, M. Duris, A. Dusza-Dobek, O.A. Eggen, M. Eklund, V. Ernsten, P. Filzmoser, D.M.A. Flight, S. Forrester, U. Fügedi, A. Gilcucis, V. Gregorauskiene, W. De Groot, A. Gulan, E. Haslinger, P. Hayoz, J. Hoogewerff, H. Hrvatovic, S. Husnjak, L. Janik, G. Jordan, M. Kaminari, J. Kirby, V. Klos, P. Kwecko, L. Kuti, A. Lima, J. Locutura, P. Lucivjansky, A. Mann, D. Mackovych, M. McLaughlin, B. I. Malyuk, R. Maquil, R.G. Meuli, G. Mol, P. Negrel, P. O'Connor, R.T. Ottesen, A. Pasnieczna, V. Petersell, S. Pfleiderer, M. Ponavic, C. Prazeres, S. Radusinovic, I. Salpeteur, R. Scanlon, A. Schedl, A. Scheib, I. Schoeters, P. Sefcik, E. Sellersjo, I. Slaninka, J.M. Soriano-Disla, A._Sorsa, R. Svrkota, T. Stafilov, T. Tarvainen, V. Tendavilov, P. Valera, V. Verougstraete, D. Vidojevic, Z. Zomeni, A. Zissimos 